\title{
Perceptions and Knowledge about Cervical Cancer among Women Living with HIV in Parakou in 2017
}

\author{
Luc Béhanzin ${ }^{*}$, Luc Valère Codjo Brun², Elfried Salanon1, \\ Marie-Claire Assomption Oloufoudi Balle Pognon², Ella Goma-Matsétsée, Maurice Agonnoudé1, \\ David Houéto', Thierry Adoukonou' ${ }^{1}$, Benjamin Hounkpatin ${ }^{4}$, Marie Thérèse Akélé Akpo ${ }^{5}$
}

${ }^{1}$ School of Public Health and Epidemiology, University of Parakou, Parakou, Benin

${ }^{2}$ Department of Pathological Anatomy, Faculty of Medicine, University of Parakou, Parakou, Benin

${ }^{3}$ STI Clinic (DIST), Cotonou Community Health Centre 1, Cotonou, Benin

${ }^{4}$ Obstetrics and Gynecology Service of the Hospital and University Center of the Mother and Child of Lagune (CHUMEL) of

Cotonou, Cotonou, Benin

${ }^{5}$ Laboratory of Pathological Anatomy of Cité Houéyiho, Faculty of Health Sciences of Cotonou, University of Abomey Calavi, Godomey, Benin

Email: ^bphilus2013@gmail.com

How to cite this paper: Béhanzin, L., Brun, L.V.C., Salanon, E., Balle Pognon, M.-C.A.O., Goma-Matsétsé, E., Agonnoudé, M., Houéto, D., Adoukonou, T., Hounkpatin, B. and Akele Akpo, M.T. (2022) Perceptions and Knowledge about Cervical Cancer among Women Living with HIV in Parakou in 2017. Open Journal of Epidemiology, 12, 31-49.

https://doi.org/10.4236/ojepi.2022.121003

Received: December 13, 2021

Accepted: January 22, 2022

Published: January 25, 2022

Copyright ( 2022 by author(s) and Scientific Research Publishing Inc. This work is licensed under the Creative Commons Attribution International License (CC BY 4.0).

http://creativecommons.org/licenses/by/4.0/ (c) (i) Open Access

\begin{abstract}
Background: Cervical cancer (CC) is the fourth most common cancer in women and those living with HIV have a six times higher risk of cervical cancer compared to those without. The objective of this study was to assess knowledge and perceptions about cervical cancer in women living with HIV/AIDS (WLWHIV) in the municipality of Parakou in Benin. Methods: This was an analytical cross-sectional study conducted among WLWHIV monitored on antiretrovira (ARV) therapy (ART) centers in Parakou. Study participants were selected by systematic random sampling technique. Data collection took place from September 5, 2017 to November 6, 2017. Log-binomial regression was used to identify associated factors. Results: A total of 167 women were recruited into the study. The median age was 35 years [Interquartile range: 41.50 - 30.00]. More than half of the women had no perception of the cause of CC. Only $12.6 \%$ of women believed in the preventive capacity of early screening of CC. Among women, $15.6 \%$ knew that it can be prevented, but only $9.6 \%$ had heard of HPV and $4.8 \%$ knew that HPV vaccination is an effective means of preventing CC. The factors associated with the low level of knowledge were the age at first sexual intercourse $(\leq 24$ years), the ART follow-up site (private health structure) and the fact of not having visited a maternity hospital in the last 12 months preceding the survey. Conclusion: The perceptions and knowledge about cervical cancer in the population of women living with HIV and monitored on ART in Parakou
\end{abstract}


were inadequate and disproportionate to their vulnerability to this cancer. In order to avoid a double burden on these women, their ART centers must integrate cervical cancer prevention interventions into ART initiation services.

\section{Keywords}

Perceptions, Knowledge, Cervical Cancer, Benin, HIV

\section{Introduction}

Cervical cancer is a major public health problem that affects middle-aged women, particularly in low- and middle-income countries [1]. In 2020 more than 600,000 women were diagnosed with cervical cancer worldwide and approximately 340,000 women died from the disease when $90 \%$ of those occur in low-income and middle-income countries that lack organized screening and HPV vaccination programs [1] [2]. Cervical cancer was the fourth most diagnosed cancer type in women, after breast cancer, colorectal cancer, and lung cancer [1]. While access to antiretroviral therapy begins reducing AIDS mortality worldwide, gynecologic oncologists warn that women being treated for AIDS could end up dying of cervical cancer unless they have access to appropriate screening and treatment [3]. Cervical cancer originates from Sexual infection with Human Papilloma Virus (HPV) which silently grows in the cervix and later develops to invasive cervical cancer [3]. It has been observed that the incidences of HPV related cell changes are related to the functioning of the immune system and living with HIV have a six-fold increased risk of cervical cancer compared with those HIV seronegative (RR: 6.07, 95\% CI 4.40 - 8.37) [3] [4] [5].

$\mathrm{HPV}$ is estimated to be the cause of $99 \%$ of cervical cancers and there is no evidence of significant genetic predisposition for cervical cancer, when the route of HPV transmission is primarily through skin-to-skin or skin-to-mucosa contact [6]. According to a study conducted in the general population in Parakou in 2012 , the prevalence of precancerous lesions of the uterine cervix was $6.81 \%$ and that of cancerous lesions was $1.04 \%$ [7]. A data collection covering a six-year period (2010-2015) within the two great hospitals of the biggest city of North Benin reported that, of the 90 cases of gynecological and breast cancers recorded during this period, cervical cancer was the leading one with $54.44 \%$ [8]. In women living with HIV monitored at the Centre Hospitalier Universitaire Departemental (CHUD) of Borgou, a study conducted in the hospital reported a frequency of $36.90 \%$ [9]. However, this cancer is preventable through key interventions including HPV vaccination in girls aged 9 to 14 , healthy sex education for boys and girls, as well as screening for precancerous lesions in eligible women with a rapid treatment of HIV-positive people [10]. The low level of education, ignorance and under-information favor the genesis of precancerous and cancerous lesions in the population of Parakou [7]. It is reported that the uptake 
rate for screening is lower among women living with HIV (WLWHIV) compared to those in the general population [9] [11]. Studies have reported that the knowledge of women living with HIV about cervical cancer is influenced by their relative experience of their HIV status [12] [13], and the use of health services [14] [15]. In Parakou, as so far as we know, no studies have been carried out on the level of WLWHIV knowledge and perceptions about cervical cancer. In this paper, we are presenting the results of a study on perceptions and knowledge about cervical cancer among women living with HIV in Parakou.

\section{Methods}

\subsection{Study Sites}

This analytical cross-sectional study was conducted in the municipality of Parakou in Borgou department in Benin. This study was carried out at the two antiretroviral therapy (ART) centers in Parakou that provided comprehensive services to all persons living with HIV (PLHIV) in the municipality. These two centers were the Department of Internal Medicine of Centre Hospitalier Universitaire Départemental du Borgou (CHUD-B) and the health center of the NGO “OSV Jordan"

\subsection{Sampling, Recruitment, and Data Collection}

Data collection took place from September 5, 2017 to November 6, 2017. The sampling frame consisted of WLWHIV monitored in the two ART sites. A systematic random sampling was used to select the participants enrolled in the study; the minimized sample size was calculated using the formula of Schwartz increased by $10 \%$ for preserving statistical power because of refusal to participate in the study. One hundred and seventy-two participants were interviewed to participate in the study. The participants were recruited gradually into the study according to their follow-up program in the two treatment centers. Data collection was done through face-to-face administration questionnaire by one-on-one interview. The questionnaire included variables such as knowledge, perceptions, screening history, a standardized tool for assessing knowledge and perceptions made up of a series of statements on which the participant agrees or disagrees. It is made up of several subscales of which we have only used the subscales perception of identity, perception of chronicity, perception of causes, perception of curability, perception of consequences as well as emotional representations. The participants's medical files were also used for sourcing data.

A knowledge level score was determined from a scale adapted from those used in the knowledge assessments by Essink-Bot et al. as well as Koneru et al. [15] [16]. This scale consisted of five items (knowledge of cervical cancer prevention, knowledge of treatment, knowledge of cervical cancer screening, knowledge of the causes and knowledge of HPV). The level of knowledge was considered low for participants with a total score of less than six as in the study by Jolly et al. and considered acceptable for patients with a score greater than or equal to six 
(06). In addition, perceptions were assessed through the Revised Illness Perception Questionnaire (R-IPQ) [17] [18].

\subsection{Eligibility Criteria}

The study population consisted of WLWHIV monitored in one of the two ART centers in the municipality of Parakou in 2017. The study included women who were sexually active and who gave their verbal, free and informed consent to participate in the study. Subjects meeting the inclusion criteria but unable to answer the questions were not included in the study.

\subsection{Statistical Analysis}

Data were double entered with IBM SPSS version 21 software for controlled data processing. Data were analyzed using $\mathrm{R}$ software.

The parameters of central tendencies and dispersion were used to describe the quantitative variables and the proportions for the qualitative variables with their confidence intervals (CI). Pearson's statistical chi-square test was used for the comparison of proportions. Factors associated with low level of knowledge were identified by log-binomial regression. The level of knowledge greater than or equal to six as an acceptable level of knowledge (coded 0), and the level of knowledge less than six as a low level of knowledge (coded 1). The selection of the parsimonious model was made using a top-down approach. Only the variables with a statistically significant association at the $20 \%$ threshold were included in the full starting model. A type I error of $5 \%$ was chosen for the statistical interpretations in the study.

\subsection{Ethical Considerations}

Verbal informed consent was obtained from each of the participants in the study. The study was approved by the ethics committee of the University of Parakou, Benin.

\section{Results}

In total, of the 172 participants interviewed to participate in the study, 167 women accepted and were included in this study, for a participation rate of $97 \%$. The majority (90.4\%) of them have a low level of knowledge, so only $9.6 \%$ of them have a level of knowledge deemed acceptable.

\section{Description of the study population}

The median age was 35 years [Interquartile range: $41.50-30.00$ ], and the mean age was $35.84 \pm 8.59$ years. About $60 \%$ of the women were over 33 years old. More than three in four women $(75.44 \%)$ were uneducated. Women traders were the most represented (51.8\%). Only one in ten women had multiple gestations. Very few $(9.58 \%)$ of women were on contraception. Regarding the age at first intercourse, $93.41 \%$ of women had their first intercourse at age 24 or earlier (Table 1). 
Table 1. Distribution of women living with HIV/AIDS according to their characteristics, commune of Parakou, Benin, 2017.

\begin{tabular}{|c|c|c|}
\hline & $\mathbf{n}$ & $\%$ \\
\hline \multicolumn{3}{|c|}{ Age $(\mathrm{N}=165)$} \\
\hline \multicolumn{3}{|l|}{ Mean age $\pm \mathrm{SD}^{*}$} \\
\hline Median age $(\mathrm{IQR})^{\star *}$ & Median age $(\mathrm{IQR})^{\star *}$ & \\
\hline \multicolumn{3}{|c|}{ Age group } \\
\hline$\leq 33$ & 65 & 38.92 \\
\hline$>33$ & 100 & 59.88 \\
\hline \multicolumn{3}{|c|}{ Education $(\mathrm{N}=167)$} \\
\hline Schooled & 41 & 24.55 \\
\hline Unschooled & 126 & 75.44 \\
\hline \multicolumn{3}{|c|}{ Profession $(\mathrm{N}=166)$} \\
\hline Farmer & 10 & 6.02 \\
\hline Housewife & 28 & 16.87 \\
\hline Retailer & 86 & 51.81 \\
\hline Working woman & 12 & 7.23 \\
\hline Civil servant & 9 & 5.42 \\
\hline Retired & 2 & 1.20 \\
\hline Student/pupil & 8 & 4.82 \\
\hline Other & 11 & 6.63 \\
\hline \multicolumn{3}{|c|}{ Contraception $(\mathrm{N}=167)$} \\
\hline Yes & 16 & 9.58 \\
\hline No & 151 & 90.42 \\
\hline \multicolumn{3}{|c|}{ Gestation $(\mathrm{N}=167)$} \\
\hline$\leq 6$ & 152 & 91.01 \\
\hline$>6$ & 15 & 8.98 \\
\hline \multicolumn{3}{|c|}{ Age at the first sexual intercourse $(\mathrm{N}=167)$} \\
\hline$\leq 24$ & 156 & 93.41 \\
\hline$>24$ & 11 & 6.59 \\
\hline \multicolumn{3}{|c|}{ Attending a maternity ward during the last 12 months $(\mathrm{N}=167)$} \\
\hline Yes & 19 & 11.37 \\
\hline No & 148 & 88.62 \\
\hline \multicolumn{3}{|c|}{ Study site $(\mathrm{N}=167)$} \\
\hline CHUD & 142 & 85.02 \\
\hline JORDAN & 25 & 14.97 \\
\hline
\end{tabular}

*standard deviation; ${ }^{* *}$ interval quartile range. 


\section{Knowledge about screening}

Few (15.6\%) of women living with HIV knew that cervical cancer can be prevented. Very few $(9.6 \%)$ of women have heard of HPV, few of these women (7.2\%) knew that HPV is transmissible and obviously very few (4.8\%) recognize that vaccination against HPV is a means of prevention against cervical cancer. Few $(7.8 \%)$ of them also agree that early detection of cervical cancer improves its prognosis (Table 2).

\section{Perceptions of the causes and curability of cervical cancer}

Almost all (98.8\%) of women living with HIV do not perceive cervical cancer as a chronic disease. But they don't see them as being able to improve naturally (95.2\%). More than half $(57.5 \%)$ have no idea of the cause of cervical cancer. However 42 other women that are $25 \%$ of women perceive a behavioral, biological or environmental cause (Table 3).

Table 2. Distribution of women living with HIV/AIDS according to their knowledge of cervical cancer prevention, municipality of Parakou, Benin, 2017.

\begin{tabular}{|c|c|c|}
\hline Items & $\mathrm{n}$ & $\%$ \\
\hline \multicolumn{3}{|l|}{ Knowledge of HPV $(\mathrm{N}=167)$} \\
\hline Have you heard of HPV? & 16 & 9.6 \\
\hline In your opinion, can HPV infection be transmitted? & 12 & 7.2 \\
\hline \multicolumn{3}{|l|}{ Screening $(\mathrm{N}=167)$} \\
\hline Knowledge of a local screening center & 18 & 10.8 \\
\hline Knowledge of the recommended screening frequency & 21 & 12.6 \\
\hline Knowledge of screening methods (IVA/IVL) & 9 & 5.4 \\
\hline Have already performed screening once & 9 & 5.4 \\
\hline \multicolumn{3}{|l|}{ Prevention $(\mathrm{N}=167)$} \\
\hline Cervical cancer can be prevented & 26 & 15.6 \\
\hline \multicolumn{3}{|l|}{ Knowledge of prevention means } \\
\hline Have few partners & 12 & 7.2 \\
\hline Condom use & 18 & 10.8 \\
\hline Loyalty to a unique partner & 11 & 6.6 \\
\hline Abstinence & 7 & 4.2 \\
\hline HPV vaccination & 8 & 4.8 \\
\hline Knowledge of frequency of screening & 31 & 18.6 \\
\hline \multicolumn{3}{|l|}{ Treatment $(\mathrm{N}=167)$} \\
\hline Curability & 6 & 3.6 \\
\hline Early screening improves prognosis for cervical cancer & 13 & 7.8 \\
\hline
\end{tabular}


Table 3. Distribution of women living with HIV according to their perceptions of cervical cancer, municipality of Parakou, Benin, 2017.

\begin{tabular}{|c|c|c|}
\hline Modalities & $\mathrm{n}$ & $\%$ \\
\hline \multicolumn{3}{|l|}{ Perception of prevention $(\mathrm{N}=167)$} \\
\hline Belief in the preventive capacity of early screening & 21 & 12.6 \\
\hline Belief in cervical cancer prevention & 26 & 15.6 \\
\hline \multicolumn{3}{|l|}{ Perception of causes $(\mathrm{N}=167)$} \\
\hline Cervical cancer has a behavioral cause & 31 & 18.6 \\
\hline Cervical cancer is fluke or bad luck & 29 & 17.4 \\
\hline Cervical cancer has a biological cause & 5 & 3.0 \\
\hline Cervical cancer has an environmental cause & 6 & 3.6 \\
\hline No perception of the cause of cervical cancer & 96 & 57.5 \\
\hline \multicolumn{3}{|l|}{ Temporality $(\mathrm{N}=167)$} \\
\hline Cervical cancer is a chronic disease & 2 & 1.2 \\
\hline Cervical cancer is always screened with a delay & 7 & 4.2 \\
\hline $\begin{array}{l}\text { Cervical cancer gets better naturally without treatment } \\
\text { (prayer, religious practices) }\end{array}$ & 8 & 4.8 \\
\hline
\end{tabular}

Factors associated with low level of knowledge about cervical cancer

The low level of knowledge about cervical cancer was 23\% times less observed in the women monitored at CHUD-Borgou compared to those monitored at the health center of the NGO "OSV Jordan", and this observed difference was statistically significant at the threshold of $5 \%$ (Table 4).

The low level of knowledge about cervical cancer was $21 \%$ times less observed in women who had their first sexual intercourse at a later age ( $>24$ years) compared to those who had it at a younger age, and this observed difference was statistically significant at the threshold of $5 \%$. In addition, linearly, the later the woman had her first sexual intercourse the more knowledge she had about cervical cancer and this trend observed in age at the first intercourse was statistically significant at the $5 \%$ level (Table 4 ).

The low level of knowledge about cervical cancer was $17 \%$ times less observed in women who attended a maternity hospital in the last 12 months preceding the survey, and this observed difference was statistically significant at the $5 \%$ level (Table 4).

\section{Discussion}

The majority (90.4\%) of the women in our study have a low level of knowledge about cervical cancer. Very few (9.6\%) of women living with HIV (WLWHIV) have heard of HPV and $7.2 \%$ of them know that HPV infection is transmissible. More than half (57.5\%) have no idea of the cause of cervical cancer. Even if very few $(9.6 \%)$ of the women in the study had an acceptable level of knowledge about cervical cancer, the later the age at first sexual intercourse in women, 
Table 4. Associated factors from multivariate log-binomial regression with low level of knowledge on cervical cancer among women living with HIV in municipality of Parakou, Benin, 2017.

\begin{tabular}{|c|c|c|c|c|}
\hline & Prevalence $\mathrm{n} / \mathrm{N}(\%)$ & Adjusted Prevalence ratio & $95 \% \mathrm{CI}^{*}$ & $\mathrm{p}$ trend $^{* *}$ \\
\hline \multicolumn{4}{|c|}{ Study site } & \\
\hline Jordan & $18 / 25(72.00)$ & 1 & & \\
\hline CHUD & $133 / 142(96.66)$ & 0.77 & $0.55-0.88$ & \\
\hline \multicolumn{4}{|c|}{ Age at the first sexual intercourse } & \multirow{3}{*}{0.023} \\
\hline$\leq 24$ & $143 / 156(91.67)$ & 1 & & \\
\hline$>24$ & $8 / 11(72.73)$ & 0.79 & $0.68-0.91$ & \\
\hline \multicolumn{4}{|c|}{ Attending a maternity ward during the last 12 months } & \\
\hline No & $133 / 142(93.66)$ & 1 & & \\
\hline Yes & $18 / 25(72.00$ & 0.83 & $0.09-0.87$ & \\
\hline
\end{tabular}

${ }^{*} 95 \%$ Confidence Interval from multivariate log-binomial regression model adjusted for age and education level.

the higher their level of knowledge. Attending a maternity ward in the past 12 months preceding the survey was also a factor in facilitating knowledge about cervical cancer. The socio-economic level of these women could be judged low by the proxy made up of the fact that they were mostly unschooled (75.44\%) with the profession of retailer or housewife representing $68.68 \%$ of them [19] [20]. In our study, WLWHIV and monitored at the Centre Departemental Hospitalier Universitaire (CHUD), had more knowledge about cervical cancer than the others who were followed at the NGO health center "OSV-Jordan". Consistent with the low socioeconomic level of women in our study population, maternity clinics attended in the past 12 months were obviously public ones that are generally more financially accessible and yet have more skills in counseling, provide women with services, information and education on their reproductive health compared to private or faith-based health centers, because the staff of public health centers benefit from training in national mother and child health programs [21]. As part of the integration of health services, women attending public health centers and in particular hospitals should have been systematically informed about the risks associated with reproductive health, including those of cervical cancer [22]. The low level of knowledge found in our study could be explained by the lack of integration of health services vis-à-vis WLWHIV monitored; screening may already be included in the minimum service package at the initiation of antiretroviral therapy (ART). The fragmentation of the HIV and cervical cancer services could have been a major barrier of Knowledge about Cervical Cancer Screening. Cervical cancer prevention education would have been routinely incorporated in HIV care among these WLWHIV. Indeed, in a qualitative study on perceptions and knowledge about cervical cancer in Malawi in 2018, WLWHIV reported that "It is better if doctors examine us as we are starting ARVs as part of our care package and follow up within our ARV ap- 
pointment dates rather than going to cervical cancer screening clinic to save transport money and time", and thus, the authors believe that access to screening services was a major barrier to screening services rather than socio-economic factors [23]. Beyond the access to screening services, these later authors identified also three other major themes influencing screening which include knowledge and attitudes, social support Networks and socio-cultural factors [23]. Drivers of lack of knowledge for cervical cancer could have been limited awareness programs, lack of knowledge among health workers, donor prioritization of other infectious diseases, infancy of cervical cancer interventions [24]. In our study the level of knowledge was low. This low level of knowledge found in our study has also been reported by several studies [16] [23] [25], where in overall HIV positive women have low knowledge regarding cervical cancer and screening as any other women [23]. In the study of Tanzania in 2017 among WLWHIV it was reported that most women (382/399 [95.7\%]) did not know about peer navigators to reduce barriers to cervical cancer screening and treatment among women with HIV infection in Tanzania [16]. In the study in San Fernando in US in 2018, many respondents (60\%) of women did not know that HPV infection increases the risk for cervical cancer and women with HPV are at higher risk for and had limited knowledge about HPV and HPV vaccination [25]. In our study, the high rate of formal non-education (75.44\%) of the population could partly explain this low level of knowledge about cervical cancer. Indeed, studies have reported that education strongly influences the adoption of cervical cancer prevention behaviors [26] [27].

Our study reported that young age at first intercourse is a risk factor for low level of knowledge; which resulted in the fact that the low level of knowledge was found more significantly in women aged 24 and under compared to the oldest. This increasing trend of knowledge with age at first intercourse is consistent with the results of the study by Martyn et al. in 2012, which indicated that the young age at first sexual intercourse is an important risk factor for cervical cancer, which meant that first cervical infection with HPV often occurs soon after first sexual intercourse, so early age at first sexual intercourse is a reasonable proxy for early age at first exposure to HPV [28].

WLWHIV are a subpopulation at higher risk for cervical cancer compared to all other women [23], and immunosuppression by HIV infection promotes multiple, large and extensive lesions. Cervical cancer is caused by HPV. It is the direct consequence of a precancerous dysplastic course due to an oncogenic HPV. Infection alone is not sufficient to induce cancer: dietary, physicochemical or genetic cofactors are needed. It is a chronic disease that fundamentally responds to prevention strategies. Beyond the measures of the essential strategy based on the development of a health policy for the integration of services, the screening smear which will detect pre-cancerous cells of the cervix or the presence of the HPV virus and vaccination against HPV are the two effective means of prevention. In addition to these two means of prevention, there is the elimination of the factors that favor the onset of cancer from this cancer. 
In our study, few $(25.15 \%)$ of women believed in the existence of a cause. whether behavioral (18.6\%), environmental $(3.6 \%)$ or biological $(3.0 \%)$, in the occurrence of cervical cancer, $15.6 \%$ believed in the prevention of cervical cancer and $12.6 \%$ believed in the preventive capacity of early detection. These proportions are low compared to those found in a general population study of women in Kenya, which were $23 \%$ for the existence of a cause, $72 \%$ for the knowledge of preventive measures and $73 \%$ for the preventive capacity of early detection [24]. It can be postulated that these low levels of knowledge and belief in the population of WLWHIV may also explain their vulnerability to the development of cervical cancer in addition to the physio-pathogenic explanations. When you think about risk factors, it helps to focus on those you can change or avoid rather than those you cannot [29]. The risk factors you can possibly change including Human papillomavirus (HPV) infection which is the most important risk factor for cervical cancer [30], sexual history (becoming sexually active at a young age, especially younger than 18 years old), having many sexual partners, having one partner who is considered high risk (someone with HPV infection or who has many sexual partners), smoking (Tobacco by-products have been found in the cervical mucus of women who smoke when researchers believe that these substances damage the DNA of cervix cells and may contribute to the development of cervical cancer, and smoking also makes the immune system less effective in fighting HPV infections) [31], having a weakened immune system (the virus that causes AIDS, weakens the immune system and puts people at higher risk for HPV infections) [3] [4] [5], Chlamydia infection (Chlamydia bacteria may help HPV grow and live on in the cervix which may increase the risk of cervical cancer) [32] [33], long-term use of oral contraceptives (Research suggests that the risk of cervical cancer goes up the longer a woman takes OCs, but the risk goes back down again after the OCs are stopped, and returns to normal many years after stopping), having multiple full-term pregnancies (Women who have had 3 or more full-term pregnancies have an increased risk of developing cervical cancer or pregnant women might have weaker immune systems, allowing for HPV infection and cancer growth), young age at first full-term pregnancy (women who were younger than 20 years when they had their first full-term pregnancy are more likely to get cervical cancer later in life than women who waited to get pregnant until they were 25 years or older), economic status (many low-income women do not have easy access to adequate health care services, including cervical cancer screening with Pap tests and HPV tests), a diet low in fruits and vegetables (women whose diets don't include enough fruits and vegetables may be at increased risk for cervical cancer) [34] and according to the same American Cancer Society, there are risk factors that cannot be changed including hormonotherapy on pregnant like Diethylstilbestrol (the risk appears to be greatest in women whose mothers took the drug during their first 16 weeks of pregnancy [35], and having a family history of cervical cancer [29]).

In our study, only $4.8 \%$ of the participants knew that vaccination against HPV 
infection was a means of preventing cervical cancer. This is proof of their really low level of knowledge about cervical cancer. The lack of integration of reproductive health services among women living with HIV normally at the initiation of ART puts them under the double burden of HIV and cervical cancer, which are two positively interacting infections [6]. It is recognized that HPV infection is the cause of cervical cancer in $99 \%$ of cases [6]. Therefore, cervical cancer can be considered a transmissible infection. This highly contagious virus is spread by simple sexual contact, even without penetration. And the condom does not protect against HPV.

To date, more than 100 types of HPV have been identified, 15 of which are considered carcinogenic [36] [37]. These high-risk types are among others, HPV-16, HPV-18, HPV-31, HPV-33, HPV-35, HPV-39, HPV-45, HPV-51, HPV-52, HPV-56, HPV -58, HPV-59, HPV-68, HPV-73 and VPH-82 [37].

In Parakou there was no cervical cancer control program. It was only recently in March 2021 that the Claudine Talon Foundation in the continuation of the Care4Afrique project ("Cancer Remedy in 4 African countries") through a new program entitled "Fight against cervical cancer" established the Borgou branch, the department integrating the municipality of Parakou. This program will focus on screening and free management of precancerous lesions of the cervix for women aged 25 to 49 .

The data collection technique used was a structured face-to-face interview. It seemed the best suited due to the inability of some participants to complete the questionnaire on their own. But as in any survey with data collected by this technique, there was a potential bias in social desirability. However, the collection being done by our small research team and well trained in this collection, even if this bias was active, it could only be non-differential and was in no way likely to distort our measures of association.

There were five (05) refusals to participate in the study, for a refusal rate of approximately $3 \%$. Moreover, these five potential participants who refused had no difference compared to the 167 who participated in the study. Indeed, among other things, only one of the women was in school, and all of them are of ages covered by the interquartile range. These refusals were not then likely to distort the representativeness of our sample as the systematic random sampling already ensures the representativeness of the sample.

We collected our data from two different ART sites. It is possible that the site was a modifying variable for our measures of association. But this would not have had a significant effect in our context given our systematic random sampling in which all individuals from both sites were ultimately considered to be from the same site before assigning sample numbers.

Our study population were women living with HIV who were followed in two outpatient treatment centers. Women who were monitored in other non-formal structures were eliminated when they could have particular characteristics such as socioeconomic level. But given the generally low socioeconomic level of the 
women of Parakou, such a situation would have been insignificant and could not deteriorate our measures of association. Moreover, since it was unintentional, if a bias was slipped into it, it could only be non-differential, only bringing the measure of association closer to its zero value without degrading the statistical significance.

Another limitation to our study was the cross-sectional design with its disadvantage of the phenomenon of temporality. But this was not of fundamental concern to us, as our study did not pretend to establish any causal link.

\section{Conclusion}

Perceptions and knowledge about cervical cancer in the population of women living with HIV and monitored at an ART site in Parakou were inadequate and disproportionate to their vulnerability to this cancer. The integration of reproductive health services including the prevention of cervical cancer into ART services, useful for initiating ART, is fundamental for the early detection and early management of patients with precancerous and cancerous lesions in order to reduce the heavy burden of this disease on these women. Along with the promotion of universal HPV vaccination for girls, efforts must be made to reduce health inequalities linked to cervical cancer, especially among women already living with the burden of HIV infection.

\section{Conflicts of Interest}

The authors declare no conflicts of interest regarding the publication of this paper.

\section{References}

[1] World Health Organization (WHO) and International Agency for Research on Cancer (IARC) (2021) Cervical Cancer Awareness Month 2021. https://www.iarc.who.int/faq/cervical-cancer-awareness-month-2021-qa/

[2] Cohen, P.A., Jhingran, A., Oaknin, A. and Denny, L. (2019) Cervical Cancer. The Lancet, 393, 169-182. https://doi.org/10.1016/S0140-6736(18)32470-X

[3] Health Systems Trust (2021) Cervical Cancer and HIV: The Intimate Connection. https://www.hst.org.za/publications/HST\%20Publications/Cervical\%20Cancer\%20a nd\%20HIV\%20The\%20intimate\%20connection.pdf

[4] Stelzle, D., Tanaka, L.F., Lee, K.K., Khalil, A.I., Baussano, I., Shah, A.S.V., McAllister, D.A., Gottlieb, S.L., Klug, S.J., Winkler, A.S., Bray, F., Baggaley, R., Clifford, G.M., Broutet, N. and Dalal, S. (2020) Estimates of the Global Burden of Cervical Cancer Associated with HIV. The Lancet Global Health, 9, E161-E169. https://doi.org/10.1016/S2214-109X(20)30459-9

[5] Greslin, I., Mougin, C. and Seilles, E. (1998) Biologie des infections à Papillomavirus. III. Response Immunitaire. Annales de Biologie Clinique, 56, 267-276.

[6] Petca, A., Borislavschi, A., Zvanca, M.E., Petca, R.C., Sandru, F. and Dumitrascu, M.C. (2020) Non-Sexual HPV Transmission and Role of Vaccination for a Better Future (Review). Experimental and Therapeutic Medicine, 20, Article No. 186. https://doi.org/10.3892/etm.2020.9316 
[7] Salifou, K., Brun, L., Akpona, L.F.J., Obossou, A.A.A. and Perrin, R.X. (2015) Facteurs associés aux lésions précancéreuses et cancéreuses du col de l'utérus dans la ville de Parakou au Bénin. European Scientific Journal (ES), 11, 275-283.

[8] Obossou, A.A.A., Tognifode, M.V., Brun, L., Balle, M.C., Denakpo, J.L., Akpo, E.M., Hpunkpatin, B.I.B., Hounkponou, N.F., Salifou, K., Sidi, I.R., Vodouhe, M.V. and Perrin, R.X. (2017) Epidemiology and Management of Gynecological and Breast Cancers in the Two Reference Hospitals of Parakou, in North Benin. Oncology and Cancer Case Reports, 3, Article No. 133.

[9] Lassissi, M. (2011) Prevalence et facteurs predictifs des lesions précancéreuses du col utérin au CHUD-B en 2010. Thèse Médecine, Univerté de Parakou, Parakou, 71 p.

[10] Fondation Claudine Talon (2021) Lutte contre le cancer du col de l'utérus. https://fondationclaudinetalon.org/index.php/lutte-cancer-col-uterus/

[11] Ministère des Solidarités et de la Santé (France) (2010) Rapport 2010 sur la prise en charge médicale des personnes infectées par le VIH sous la direction du Pr. Patrick Yéni. https://solidarites-sante.gouv.fr/ministere/documentation-et-publications-officielles /rapports/sante/article/rapport-2010-sur-la-prise-en-charge-medicale-des-personne s-infectees-par-le-vih

[12] Chen, Y.Y.B., Li, A.T.W., Fung, P.L. and Wong, J.P.H. (2015) Improving Access to Mental Health Services for Racialized Immigrants, Refugees, and Non-Status People Living with HIV/AIDS. Journal of Health Care for the Poor and Underserved, 26, 505-518. https://doi.org/10.1353/hpu.2015.0049

[13] Logle, C., James, L., Tharao, W. and Loutfy, M. (2011) HIV, Gender, Race, Sexual Orientation, and Sex Work: A Qualitative Study of Intersectional Stigma Experienced by HIV-Positive Women in Ontario, Canada. PLoS Medicine, 8, e1001124. https://doi.org/10.1371/journal.pmed.1001124

[14] Flores, B.E. and Acton, G.J. (2013) Older Hispanic Women, Health Literacy, and Cervical Cancer Screening. Clinical Nursing Research, 22, 402-415. https://doi.org/10.1177/1054773813489309

[15] Essink-Bot, M.L., Dekker, E., Timmermans, D.R.M., Uiters, E. and Fransen, M.P. (2016) Knowledge and Informed Decision-Making about Population-Based Colorectal Cancer Screening Participation in Groups with Low and Adequate Health Literacy. Gastroenterology Research and Practice, 2016, Article ID: 7292369. https://doi.org/10.1155/2016/7292369

[16] Koneru, A., Jolly, P.E., Blakemore, S., McCree, R., Lisovicz, N.F., Aris, E.A., Mtesigwa, T., Yuma, S. and Mwaiselage, J.D. (2017) Acceptance of Peer Navigators to Reduce Barriers to Cervical Cancer Screening and Treatment among Women with HIV Infection in Tanzania. International Journal of Gynecology \& Obstetrics, 138 , 53-61. https://doi.org/10.1002/ijgo.12174

[17] Moss-Morris, R., Weinman, J., Petris, K.J., Horne, R., Cameron, L.D. and Buick, D. (2002) The Revised Illness Perception Questionnaire (IPQ-R). Psychology and Health, 17, 1-16. https://doi.org/10.1080/08870440290001494

[18] Broadbent, E., Wilkes, C., Koschwanez, H., Weinman, J., Norton, S. and Petrie, K.J. (2015) A Systematic Review and Meta-Analysis of the Brief Illness Perception Questionnaire. Psychology \& Health, 30, 1361-1385. https://doi.org/10.1080/08870446.2015.1070851

[19] Syeda, A.H. and Nazish, R. (2017) The Role of Female Education in Economic Growth of Pakistan: A Time Series Analysis from 1990-2016. International Journal of Innovation and Economics Development, 3, 83-93. 
https://doi.org/10.18775/ijied.1849-7551-7020.2015.35.2007

[20] Geeta, G.K. (2002) Education of Women and Socio-Economic Development. In: Fazel, S. and Lee, A.A., Eds., Reason and Revelation: Studies in the Babi and Baha' $i$ Religions, Kalimat Press, Los Angeles, 243.

[21] Ministère de la Santé du Bénin (2008) Politique Nationale de Santé Bénin. Déclaration de Politique Nationale de Santé 2009-2018.

http://www.africanchildforum.org/clr/policy\%20per\%20country/benin/benin healt h fr.pdf

[22] Management Services for Health (2021) Integrated Health Services Activity. Stronger Health Systems. Greater Health Impact.

https://www.msh.org/our-work/projects/integrated-health-services-activity

[23] Mtengezo, J. and Lee, H. (2018) HIV-Positive Women's Perceptions, Awareness, and Knowledge about Cervical Cancer Screening in Malawi: A Qualitative Study. Journal of Molecular Microbiology, 3, 3 p.

[24] Tapera, O., Dreyer, G., Kadzatsa, W., Nyakabau, A.M., Stray-Pedersen, B. and Hendricks, S.J.H. (2019) Cervical Cancer Knowledge, Attitudes, Beliefs and Practices of Women Aged at Least 25 Years in Harare, Zimbabwe. BMC Women's Health, 19, Article No. 91. https://doi.org/10.1186/s12905-019-0790-6

[25] Bernice, W. and Noel, O.O. (2018) Knowledge and Attitude towards HPV, PAP Testing and HPV Vaccination among Women with HIV. Journal of AIDS \& Clinical Research, 9, Article ID: 1000772.

[26] Murfin, J., Irvine, F., Meechan-Rogers, R. and Swift, A. (2019) Education, Income and Occupation and Their Influence on the Uptake of Cervical Cancer Prevention Strategies: A Systematic Review. Journal of Clinical Nursing, 29, 393-415. https://doi.org/10.1111/jocn.15094

[27] Corral, F., Cueva, P., Yépez, J. and Montes, E. (1996) Limited Education as a Risk Factor in Cervical Cancer. Bulletin of the Pan American Health Organization, 30, 322-329.

[28] Plummer, M., Peto, J. and Franceschi, S. (2012) Time since First Sexual Intercourse and the Risk of Cervical Cancer. International Journal of Cancer, 130, 2638-2644. https://doi.org/10.1002/ijc.26250

[29] American Cancer Society (2021) Cervical Cancer Causes, Risk Factors, and Prevention. https://www.cancer.org/content/dam/CRC/PDF/Public/8600.00.pdf

[30] Schiffman, M., Castle, P.E., Jeronimo, J., Rodriguez, A.C. and Wacholder, S. (2007) Human Papillomavirus and Cervical Cancer. The Lancet, 370, 890-907. https://doi.org/10.1016/S0140-6736(07)61416-0

[31] Roura, E., Castellsagué, X., Pawlita, M., Travier, N., Waterboer, T., Margall, N., Bosch, F.X., de Sanjosé, S., Dillner, J., Gram, I.T., Tjønneland, A., Munk, C., Pala, V., Palli, D., Khaw, KT., Barnabas, R.V., Overvad, K., Clavel-Chapelon, F., Boutron-Ruault, M.C., Fagherazzi. G., Kaaks, R., Lukanova, A., Steffen, A., Trichopoulou, A., Trichopoulos, D., Klinaki, E., Tumino, R., Sacerdote, C., Panico, S., Bueno-de-Mesquita, H.B., Peeters, P.H., Lund, E., Weiderpass, E., Redondo, M.L., Sánchez, M.J., Tormo, M.J., Barricarte, A., Larrañaga, N., Ekström, J., Hortlund, M., Lindquist, D., Wareham, N., Travis, R.C., Rinaldi, S., Tommasino, M., Franceschi, S. and Riboli, E. (2014) Smoking as a Major Risk Factor for Cervical Cancer and Pre-Cancer: Results from the EPIC Cohort. International Journal of Cancer, 135, 453-466. https://doi.org/10.1002/ijc.28666

[32] Silva, J., Cerqueira, F. and Medeiros, R. (2014) Chlamydia trachomatis Infection: Implications for HPV Status and Cervical Cancer. Archives of Gynecology and Ob- 
stetrics, 289, 715-723. https://doi.org/10.1007/s00404-013-3122-3

[33] Zhu, H.Y., Shen, Z.J., Luo, H., Zhang, W.W. and Zhu, X.Q. (2016) Chlamydia trachomatis Infection-Associated Risk of Cervical Cancer: A Meta-Analysis. Medicine, 95, e3077. https://doi.org/10.1097/MD.0000000000003077

[34] Chih, H.J., Lee, A.H., Colville, L., Binns, C.W. and Xu, D. (2013) A Review of Dietary Prevention of Human Papillomavirus-Related Infection of the Cervix and Cervical Intraepithelial Neoplasia. Nutrition and Cancer, 65, 317-328. https://doi.org/10.1080/01635581.2013.757630

[35] Adam, E., Kaufman, R.H., Adler-Storthz, K., Melnick, J.L. and Dreesman, G.R. (1985) A Prospective Study of Association of Herpes Simplex Virus and Human Papillomavirus Infection with Cervical Neoplasia in Women Exposed to Diethylstilbestrol in Utero. International Journal of Cancer, 35, 19-26. https://doi.org/10.1002/ijc.2910350105

[36] Burd, E.M. (2003) Human Papillomavirus and Cervical Cancer. Clinical Microbiology Reviews, 16, 1-17.

[37] Muñoz, N., Bosch, F.X., de Sanjosé, S., Herrero, R., Castellsagué, X., Shah, K.V., Snijders, P.J. and Meijer, C.J. (2003) Epidemiologic Classification of Human Papillomavirus Types Associated with Cervical Cancer. The New England Journal of Medicine, 348, 518-527. https://doi.org/10.1056/NEJMoa021641 


\section{Appendix}

Cervical Cancer Perceptions and Knowledge Questionnaire (without general characteristics, behaviours and lifestyle, sexual activities, marital status).

\section{SECTION: Knowledge, Perceptions, Screening History}

\begin{tabular}{|c|c|c|c|}
\hline No & Questions and Filters & Answers and codes & Skip to \\
\hline Q01. & $\begin{array}{l}\text { Have you ever heard of HPV or } \\
\text { a disease called cervical cancer? }\end{array}$ & $\begin{array}{l}\text { Yes............... } \\
\text { No................2 } \\
\text { No response...9 }\end{array}$ & 1 \\
\hline Q02. & $\begin{array}{l}\text { Do you know anyone who has } \\
\text { suffered from Cervical Cancer or } \\
\text { died from Cervical Cancer? }\end{array}$ & $\begin{array}{l}\text { Yes................1 } \\
\text { No..................2 } \\
\text { No Response...9 }\end{array}$ & 1 \\
\hline Q03. & $\begin{array}{l}\text { How can we protect ourselves } \\
\text { against cervical cancer? } \\
\text { INTERVIEWER, several answers } \\
\text { are possible. } \\
\text { Do not suggest answers, circle } \\
\text { alphabetical letters according to } \\
\text { respondent's answers }\end{array}$ & $\begin{array}{l}\text { a) Use the condom } \\
\text { b) have few sexual partners } \\
\text { c) Be faithful to an uninfected partner } \\
\text { d) sexual abstinence } \\
\text { e) early screening } \\
\text { f) Vaccination } \\
\text { g) Other } \\
\text { h) No response }\end{array}$ & \\
\hline Q04. & $\begin{array}{l}\text { Do you think that cervical } \\
\text { cancer can be prevented by early } \\
\text { detection? }\end{array}$ & $\begin{array}{l}\text { Yes...........1 } \\
\text { No ..............2 } \\
\text { No Response...9 }\end{array}$ & 1 \\
\hline Q05. & $\begin{array}{l}\text { Is it possible to screen for cervical } \\
\text { cancer in your community? }\end{array}$ & $\begin{array}{l}\text { Yes............ } \\
\text { No................2 } \\
\text { No Response ...9 }\end{array}$ & I_ I \\
\hline Q06. & $\begin{array}{l}\text { what screening methods do you } \\
\text { know? }\end{array}$ & $\begin{array}{l}\text { VIA ........... } \\
\text { VILI............2 } \\
\text { VIA/VILI ........ } \\
\text { Uterine cervical smear test.............4 } \\
\text { biopsy for cervical cancer test....... } \\
\text { None............6 } \\
\text { Other (Specify)...7 }\end{array}$ & 1 \\
\hline Q07. & $\begin{array}{l}\text { How often should we be screened } \\
\text { for cervical cancer? }\end{array}$ & $\begin{array}{l}\text { every three years...............1 } \\
\text { every three years bitten two normal smear tests..........2 } \\
\text { every five years ...... } \\
\text { every year...........4 } \\
\text { Other (Specify) .......5 } \\
\text { Don't Know......... } 8\end{array}$ & 1 \\
\hline Q08. & $\begin{array}{l}\text { How do you think cervical cancer } \\
\text { is transmitted? }\end{array}$ & $\begin{array}{l}\text { Sexual intercourse } \ldots \ldots \ldots \ldots \ldots \ldots \ldots \ldots . . . \ldots 1 \\
\text { Unprotected sexual intercourse........... } 2 \\
\text { By dirty objects ...... } \\
\text { Other (Specify) .......4 } \\
\text { Don't Know...........8 }\end{array}$ & 1 \\
\hline Q09. & Can cervical cancer be prevented? & $\begin{array}{l}\text { Yes................. } \\
\text { No } \ldots \ldots \ldots \ldots \ldots \ldots \ldots . . .2 \\
\text { No response........... }\end{array}$ & 1 \\
\hline
\end{tabular}


Q010.

If yes enumerate the means do you know?

Vaccination............
Screening.............2
Sexual abstinence.....3
condom use............4
Don't Know...........8

Do you think early screening

Q011. for cervical cancer facilitate the management of cervical cancer?

Q012. When you discover cancer, is it always too late?

Q013.

Perceptions of cervical cancer as chronic disease?

Perceptions of the consequences of the disease

Q015. Emotional representation

Q016.

Perceptions of curability of cervical cancer
Yes. $\ldots 1$

No.....................2

No-response...........9

Yes.................1

No..................2

No-response ........9

Cervical cancer does not last long...........1

Cervical cancer is likely to be permanent rather than temporary...2

Cervical cancer progress speedily.....3

I don't think cervical cancer progress progresses throughout life...4 cervical cancer is severe ..1

cervical cancer has important consequences on life.........2

Cervical cancer does not have much effect on the person life..........3/

Cervical cancer greatly affects how others see the sufferer...........4

cervical cancer has serious financial consequences.

I get depressed when I think about cervical cancer......................

When I think to cervical cancer, I worry about it

Cervical cancer doesn't bother me.....3

Cervical cancer frightens me...........4

effective treatment can cure cervical cancer .1

Negative effects of cervical cancer can be prevented (avoided) by treatment...................2

treatment can control cervical cancer.........3

Nothing can help someone who starts cervical cancer ..........4

Q017. Perceptions of causes and risk factors

alcohol consumption....1

tobacco consumption.....2

personality type..........3

Q018. Lifestyle

My overload work.....4

my behavior...............5

Chance or bad luck...6

dietary habits.............7

a virus....................... 1

hereditary..................2

immunosuppression...3

aging..........................4

Injury, stress or trouble. .1

Aging...........................2

Solitude.........................

Abatement...................4

Anxiety.......................5

Having a negative view of oneself...........6 


\section{Continued}

Q021. Environmental pollution

Yes..................1
No $\ldots \ldots \ldots \ldots \ldots \ldots \ldots . . . .2$
No-response..........

I don't want to know the result, Yes....................1

Q022. but have you ever been tested for No .........................2

cervical cancer?

No -response ...........9

VIA .............1

VILI...............2

VIA/VILI ..........3

Q023. Specify the Method used

Q024. Who made this or these tests?

Q026. cervical cancer, the last time? INTER VIEWER, circle the correct answer.

In the last 3 years, how many

Q027. times have you tested for cervical cancer? screening, what were the circumstances under which you performed the test? INTER VIEWER, circle the correct answer

Why did you screen for Cervical

Q029. Cancer?

INTER VIEWER, circle the correct answer

c) Twice .............. 3
Uterine cervical smear test.

biopsy for cervical cancer test....... 5

None...........6

Other (Specify)...7

Don't know............ 8

gynecologist ........1

generalist physicians...............2

midwives ............... 3

Anatomo pathologist ..................................

lab technicians ......5

Others (specify)......6

Does not remember anymore . .0

Specify.
a) last 3 months
b) last 6 months
c) last 12 months
d) 1 to 3 years
e) More than 3 years
f) Cannot remember

a) None.............1

b) Once..............2

d) Tree times..........4

e) Four times and more 5

f) Don't know .........8

g) No response ........9

h) Does not remember .0

a) voluntary

b) by obligation

c) by medical prescription

d) other (specify)

e) No response

a) Know my status

b) A health worker proposed it to me

c) Medical prescription

d) Advice from a peer educator

e) Advice from the treating physician

f) Others (specify)

g) No response 


\section{Continued}

Positive..

. .1

So tell me if your test result was Negative ..............2

positive or negative Don't know ..............8

No response ...............9

Never thought to do..1

Q031 if not, what are the reasons why Embarrassed to be examined by a man...2 you did not screen?

not informed.

...3

Others (Specify)...

....4 